\title{
The Construction of the Homeless as a Discursive-Political Struggle: A Discursive-Theoretical Re-reading of
the Homeless Subject Position
}

NICO CARPENTIER ${ }^{1}$, VAIA DOUDAKI ${ }^{2}$

${ }^{1}$ Charles University (Czech Republic), Vrije Universiteit Brussel (Belgium) and Uppsala University (Sweden) Institute of Communication Studies and Journalism, Faculty of Social Sciences, Smetanovo nábř. 6, 11000 Praha 1, Czech Republic

${ }^{2}$ Charles University (Czech Republic) Institute of Communication Studies and Journalism, Faculty of Social Sciences, Smetanovo nábř. 6, 11000 Praha 1, Czech Republic Email: nico.carpentier@fsv.cuni.cz; vaia.doudaki@fsv.cuni.cz

\begin{abstract}
Within the literature on homelessness, the attention for what is often called 'homeless identity' is slowly increasing, and within this body of knowledge, the complex, contingent and contested nature of this identity also becomes more visible. This article aims to contribute to this discussion, by deploying Laclau and Mouffe's (1985) discourse theory to produce a (discursive-) theoretical re-reading of the homeless identity, or, in discourse-theoretical terms, the homeless subject position. Acknowledging that the homeless subject position is part of a larger assemblage, this article, in particular, aims to show the contested nature of this subject position and how it is an object of political struggle. In the second part, this article zooms in on the literature on media constructions, and the struggle over the homeless subject position in (and between) mainstream media and the so-called street press.
\end{abstract}

Keywords: post-structuralist discourse theory, subject position, homeless, mainstream media, street press

\section{INTRODUCTION}

Homeless people are very much part of modern (urban) life, and many middle-class people regularly - albeit very briefly - meet homeless people, for instance, on the streets or when travelling with public transport. Snow and Anderson (1987: 1336) start their article 'Identity Work among the Homeless' with a series of concepts that have been used to refer to those at the lowest part of the social hierarchy, which includes concepts such as ribauz, lumpenproletariat, untouchables and underclass. The middle-class gaze of us - better-off city dwellers - in the street or in the tube only seems to confirm this.

There is a vast academic literature on homelessness, where approaches oriented towards causes, consequences and solutions have a strong presence - combined with foci on particular societal groups and geographies - as we can see in Levinson's (2004) two-volume Encyclo- 
pedia of Homelessness, or in McNamara's (2008) three-volume Homelessness in America. Among these publications, the above-mentioned Snow and Anderson's article is one of the early publications that focused on the identities of homeless people, showing the complexities and diversities that characterize this social group, but also doing what still happens only too rarely - listening to homeless people. This also gently counters the significant stigma that this group is confronted with on an almost permanent basis. This article ${ }^{1}$ wants to contribute to this discussion, by deploying discourse theory, a theoretical framework that is rooted in political philosophy. In particular, Laclau and Mouffe's (1985) discourse theory has the capacity to increase our understanding of the discursive construction of the homeless subject position, but also to theorize how this construction is the object of discursive-political struggles over its meaning, for instance, in the field of media. Moreover, as one of us has argued, in The Discursive-Material Knot (Carpentier 2017) discourse theory can be deployed to engage in theoretical re-readings of existing (theoretical or analytical) literature, a method which is used in this article as well.

\section{LACLAU AND MOUFFE'S DISCOURSE THEORY}

In Hegemony and Socialist Strategy, Laclau and Mouffe (1985) provide an outline of their discourse theory, which is embedded in the post-structuralist and post-Marxist agenda. In contrast to many other approaches in discourse studies, Laclau and Mouffe's discourse theory uses a macro-textual and macro-contextual (see Carpentier 2017: 16-17) definition of discourses as frameworks of intelligibility. Discourses thus become seen as necessary instruments to give meaning to the social world, without denying the latter's material dimensions. This also implies that discourses provide subjects with points of identification, which Laclau and Mouffe (1985: 115) call subject positions. Similar to Althusser's notion of interpellation, these subject positions offer subjects the building blocks of their subjectivity, as discursive structures for the construction of the self.

Moreover, Laclau and Mouffe emphasize the structural openness of discourses, which are always vulnerable to re-articulation, avoiding an ultimate and total closure of meaning. Discourses are often coherent entities, gaining their stability from privileged signifiers - or nodal points - but this stability is never to be taken for granted, as discourses can change, become insignificant or disintegrate. This contingency also impacts on subject positions, that can never totally saturate the subject, as there are always a multiplicity of subject positions at work, and subjects construct always unique identificatory relationships with these subject positions. But at the same time, subject positions exercise considerable power, by providing structures of meaning that structure people's subjectivities, how they see, feel, experience and think others and themselves, and which subjects and groups they like or dislike, consider friends or enemies, or even consider human or not. Of course, subjects do not identify with all discourses and subject positions. In some cases, they will, but in other cases they might distance themselves, remain insensitive or become hostile towards other discourses, which implies, as Van Brussel (2018) has argued, discursive recognition without identification.

Finally, Laclau and Mouffe also strongly thematize the political dimensions of the discursive, as discourses engage in struggles with each other, over the establishment of hegemony. Not all discursive struggles result in hegemony, though, as some struggles simply continue

\footnotetext{
1 An extended version of this article will be published in the book coming out of the 2018 European Media
} and Communication Doctoral Summer School. 
without any discourse achieving victory, but in some cases a discourse manages to gain a dominant position and to transform itself into a social imaginary that can benefit from the luxury of taken-for-grantedness, normalization and eventually sedimentation. But even in this scenario, as the below example of homelessness will illustrate, counter-hegemonic discourses can contest the hegemonic discourse and offer points of resistance, creating the threat that the once victorious discourse will be removed from its (discursive) throne.

\section{CONSTRUCTIONS OF THE HOMELESS AND THE HOME}

One area where we can see this struggle at work is in relation to the subject position of the homeless person. The homeless is a subject position, contested, fluid, contradictory, object of identification and dis-identification, acceptance and rejection, but still very real in its existence. As a subject position, it is particular, because it is articulated through a series of disempowering signifiers that together form a stigma. The vortex of this stigma generates strong absorptive forces that tend to reduce the individual to this one subject position, ignoring the multiplicity of subject positions that make up a person's subjectivity. This reduction can even be found in (some of) the academic literature on homelessness, which in turn has provoked a series of critical reconsiderations of what is often called 'homeless identity', addressing the issues in the 'extensive literature focusing on homelessness and identity' where 'often homelessness is presented as constituting a discrete and one-dimensional identity that people avoid or embrace' (Parsell 2011: 443).

The homeless stigma is simultaneously discursive and material, affective and cognitive, temporal and spatial, dealing with absences and presences, working with selves and others. It is an assemblage of material routines, sleeping places, 'tattered and soiled clothes' (Snow and Anderson 1987: 1339-1340), interactions with companions, social workers, police officers, kind or aggressive passers-by, policies aimed at objectivation, disciplining, invisibility, removal and criminalization, all structured through the absence of one crucial material component: the home. Snow and Anderson (1987: 1340) describe how central antagonism to this assemblage is:

'Actual or threatened proximity to them not only engenders fear and enmity in other citizens but also frequently invites the most visceral kinds of responses, ranging from shouts of invective to organized neighborhood opposition to proposed shelter locations to "troll-busting" campaigns aimed at terrorization.'

Even if the subject position of the homeless is 'only' part of the assemblage of homelessness, it still merits our attention, because of its centrality to the operations of the stigma, and because of the hegemonic forces that attempt to construct this subject position through the stigma, objectifying and dehumanizing homeless people, denying them access to the signifiers of agency and citizenship. They become reduced to passive denizens ${ }^{2}$, that have their political, civic and social citizenship rights (Marshall 1992) reduced. But also the resistance against the hegemonic articulation of the homeless, attempting to subjectivize and humanize them(selves), makes this a highly relevant component of the assemblage of homelessness.

In the construction of the subject position of the homeless, the absence of the home - or what McCarthy (2013: 54 - referring to Swain 2011) calls 'rooflessness' - plays a crucial role,

2 Denizenship originally (see Hammar 1989) referred to the (reduced) rights of permanent residents in a foreign country. Here, we use it in the expanded meaning, as the reduced political, civil and social citizenship rights (see Marshall 1992) within a populace. Turner (2016) calls the latter denizenship type 2. 
both in articulating the subject position and in organizing the logics of stigmatization. Here, we should keep the centrality of the home in Western imaginaries in mind, as exemplified by the centrality of the home in Felski's ${ }^{3}$ (1999/2000: 18 - our emphasis) seminal definition of the everyday, as ' $<\ldots>$ grounded in three key facets: time, space and modality. The temporality of the everyday $\langle\ldots\rangle$ is that of repetition, the spatial ordering of the everyday is anchored in a sense of home and the characteristic mode of experiencing the everyday is that of habit.' In this imaginary, the home is the house, a material shelter that generates a private sphere for the (bourgeois) nuclear family, a process that Hollows (2008: 10) called the familialization of domestic culture. The home is also an archive and storage space, containing a multitude of objects, tempting Maleuvre (1999: 115) to the following description: 'it is as an owner of a great many objects that the bourgeois individual inhabits the home. To dwell is to possess. Home and property strike a perfect constellation in the concept of the private collection.'

The (possession of the) home itself functions as a normative ideal, that is actively imposed as one of the requirements of modern life. Heidegger's (1993: 363) choice for using the notion of homelessness, as a metaphor to capture alienation, is just one of the many possible illustrations of the centrality of the home in the Western imaginations. For Heidegger, home/being homed is 'a condition in which humankind is at one with itself, balanced between the earth and the sky, between physicality and spirituality', and homelessness refers to 'the alienation of that balance, an estrangement of body and spirit' (Smyth, Croft 2006: 15). Societal groups that are outside this hegemonic discourse (and its materialization into a home) are, in different degrees, subjected to interventions that aim to align their behaviour with this hegemonic discourse. Powell (2008: 88), for instance, describes how the nomadic life of Roma and Travellers exposes them to societal pressures to 'conform to a sedentary way of life'. The sedentarist hegemony - with sedentarism defined as 'the system of ideas and practices which serve to normalise and reproduce sedentary modes of existence and pathologise and repress nomadic modes of existence' (McVeigh 1997: 9) - not only affects Roma and Travellers, though. Also the subject position of the homeless is articulated through this anti-nomadist discourse, where the lack of a home is a sign of 'failure and degradation' (Hughes-Edwards 2006: 122), and 'representations of homelessness can often work to reaffirm idealized notions of domestic life in which the home is equated with "safety and security" and the streets with "fear and danger" (Hollows 2008: 121, with reference to Wardhaugh 1999: 96).

The central position of the home in Western imaginaries is not without contestations. Two key contestations are important here, as they also have the potential to impact on the stigma articulated with the subject position of the homeless. Morley's (2000: 47) emphasis on the mobile home as symbolic space (and not so much a place) represents one type of contestation, exemplified by this citation: 'home may not be so much a singular physical entity fixed in a particular place, but rather a mobile, symbolic habitat, a performative way of life and of doing things in which one makes one's home while in movement.' Even if there are many - pleasant and unpleasant - ways of organizing and experiencing mobile domesticity - consider, for instance, Richter's (2005) book Home on the Rails, about female bourgeois railroad travel the more positive evaluation of mobile domesticity also offers the potential for more benevolent articulations of the homeless subject positions. The second contestation focuses more on the problematization of the home as the site of disciplining interventions, unequal power

\footnotetext{
3 This is not to argue that Felski does not pay attention to hybridity and fluidity.
} 
relations and violence. Here, Haraway's (1991: 171-72) description of the home can be used as illustration of this contestation:

'Home: Women-headed households, serial monogamy, flight of men, old women alone, technology of domestic work, paid homework, re-emergence of home sweat-shops, homebased businesses and telecommuting, electronic cottage, urban homelessness, migration, module architecture, reinforced (simulated) nuclear family, intense domestic violence.'

\section{MEDIA STRUGGLES OVER THE CONSTRUCTIONS OF THE HOMELESS}

There are many locations where the discourses on the homeless subject position circulate, but if we take the field of the media as an example, we first of all see that in the mainstream media, homelessness is not an issue that they frequently cover. When it is addressed in this type of media content, the hegemonic discourse of homelessness is largely reproduced, conveying 'mainstream society's messages of power, influence, and authority', since '[b]y exercising our power to name, we construct a social phenomenon, homelessness, the criteria used to define it, and a stereotype of the people to whom it refers' (Daly 1996: 9). But in many cases, homeless people are not visible, and thus become - to use Tuchman's (1978) concept - symbolically annihilated. When homelessness is covered by mainstream media, episodic coverage dominates, focusing on the tragic death of an anonymous individual or on charity work being done to support homeless people (especially around the Christmas holidays) (Howley 2003: 280). Only rarely, the structural or systemic reasons of homelessness are addressed.

The mainstream media coverage of homeless people is aligned with the hegemonic discourse of stigmatization, as outlined above. Homeless people are portrayed as a 'threat' to the well-being of society, largely through 'them versus us' articulations (Whang, Min 1999a). The processes and signifying practices of othering are evident even in more sympathetic approaches of the homeless, since they are then reduced to being victims and helpless, dependent for their salvation on society's benevolence, while the rest of society is assumed to be healthy and powerful (ibid.). When they are not presented as victims, homeless people are represented as responsible for their situation. In these cases, responsibility is attributed to the individuals, disconnected from any structural causes and dimensions, employing again binary oppositional schemata (Whang, Min 1999b). Furthermore, in mainstream media, 'experts' dominate as sources on homelessness. When news about homelessness appears, the homeless remain largely absent, which renders them voiceless, whereas various authority holders speak on their behalf or (more often) against them. In the cases where homeless people are given the opportunity to speak, their role is usually 'limited to the devalued voice of experience' (Schneider 2011: 71), which contributes to the construction of the dominant discourse of the homeless and the perpetuation of their marginalization and stigmatization.

The mainstream media coverage, and its alignment with the hegemonic discourse of stigmatization and sedentarism, is not the only media environment that allows for the circulation of the homeless subject position. Some media publications explicitly resist the hegemonic discourse of homelessness, and engage in a discursive struggle over the construction of this subject position. The most poignant example is the so-called street press, which made its appearance already in the late 19th century, but has been proliferating from the (late) 1980s and (early) 1990s onward. Street News, established in New York in 1989, is considered to be the first contemporary street newspaper and has served as a prototype for street papers around the world. Also, The Big Issue, launched in London in 1991, paved the way for the flourishing of street papers across Europe. The International Network of Street Papers (INSP), founded 
in 1994, has today over 100 street papers as its members, from 34 countries, published in 24 languages (insp.ngo). As it is stated in INSP's core values, the network is 'committed to challenging inequality and social exclusion', and 'nurture[s] creative and innovative approaches to social problems' (https://insp.ngo/who-we-are/our-story/).

The street papers, circulating most often in the format of a magazine or a newspaper, demonstrate a considerable diversity as it regards their format, design, content and operational models, but also consistency as it regards their approach and philosophy. They do share a common main purpose, which is supported by their distribution model, and which is to support homeless and other socially excluded people to find their way back to society, through employment (Harter et al. 2004; Boukhari 1999; Howley 2005). Homeless and poor people are the sole vendors of these editions, having the opportunity to gain some income and potentially reconnect with society.

At the same time, the street papers have a strong focus on the coverage of issues of homelessness, poverty and social exclusion, broadening the scope of the latter by bringing more inclusive perspectives of their constituents and dimensions, and raising awareness on social inequality and injustice (Harter et al. 2004). They publish 'highly personalized accounts of life on the streets, coupled with fearless critiques of contemporary economic conditions and regressive (often repressive) social policy' (Howley 2003: 280-281). By bringing in the voices and perspectives of the homeless and poor people, but also of activists, artists and civil society, street papers broaden the perspective of what homelessness and social exclusion is, and highlight the structural dimensions of causes and effects of the increasing social and economic inequalities. As Howley argues, 'street papers challenge the basic assumption that capitalism is a viable, let alone an equitable system of human relations' (ibid.: 288).

However, there is a need to be careful with univocally celebrating street papers, especially when considering the actual range of opportunities that is offered to vendors to express themselves. Torck (2001) argues that the space given to the vendors' voices in the street papers is generally limited, and restricted to specific writing genres, like the personal narratives, a restriction that in fact perpetuates their stereotypical representations. In many cases, the street papers' vendors are not part of the management and editorial teams, which raises questions about how participatory and grassroots-based these publications are. Moreover, the search for sustainable (business) models has driven some street papers towards the (more mainstream) content of general interest, moving away from the content that is advocating for homeless people. For example, The Big Issue, whose model has been considered successful in achieving high sales, has been criticized for focusing too much on news about entertainment and the arts, not exhibiting sufficient interest in issues of homelessness or poverty and in hosting the vendors' original voices (Torck 2001). These tensions and debates reflect the different and, up to a certain degree, competing visions of the street papers' mission, and relate to their efforts to balance providing employment opportunities to the homeless (arguing for a business-oriented model) and covering issues related to social and economic injustice, by hosting the voice of the communities affected (arguing for an alternative media organization model, promoting participation in management and content production, and non-hierarchical organization).

Still, even when considering this diversity, street papers offer alternative spaces for the construction of the homeless, countering the disempowering and stigmatizing - and sometimes fear-inducing, sometimes criminalizing, sometimes patronizing - hegemonic discourse on the homeless subject position. This discursive contestation of the hegemonic 
discourse on the homeless is, arguably, located on two interrelated levels. On the one hand, street papers recognize (or identify) the hegemonic discourse, in order to then critique it, showing the gaps and contradictions in this discourse. This is an identification of a discourse, acknowledging its existence so that it can be critiqued. On the other hand, street papers tap into alternative discourses on the homeless subject position, re-articulating and re-signifying its signifiers in order to produce more respectful articulations of this subject position, that they can identify with.

\section{CONCLUSIONS}

The struggle between different discourses on the homeless subject position, as part of the homeless assemblage, shows the contingency of the homeless subject position. Homeless people can be constructed in a variety of ways, ranging from passive and stigmatized denizens without a bourgeois house, to active citizens that perform creative, mobile and multiple definitions of the home. Especially when we use a more in-depth perspective, for instance, looking at how these different articulations of the homeless subject positions co-exist in different types of media outlets, we see the contingency of identity at work. But at the same time, the 'case' of the homeless subject positions illustrates how uneven and imbalanced these discursive struggles sometimes can be. The stigma weighs heavily on the homeless subject position, and its hegemonic force structurally hinders the deployment of alternative and counter-hegemonic articulations, even if these are more respectful and humane.

The discursive struggle over the homeless subject position also raises questions about the rather exclusive focus on identification that we can find in discourse theory. Once more specific struggles, and their translations into social practice, are taken into consideration - without losing the key idea of discursive multiplicity out of sight - we can firstly see identificatory processes at work, where different actors align themselves with particular discourses, and where they all become integrated in evenly particular discursive-material assemblages. But we can also see discourses which actors do not identify with, but whose existence, as a coherent framework of intelligibility, is still recognized, for instance, in order to then critique them. This implies that when identification fails - or, to use a different concept, when interpellation fails - there is still the possibility of the recognition of discourses, that, in turn, allows for the creation of critical assemblages of rejection.

Received 29 November 2018 Accepted 5 February 2018

\section{References}

1. Boukhari, S. 1999. “The Press Takes to the Street”, UNESCO Courier 52: 43-44.

2. Carpentier, N. 2017. The Discursive-Material Knot:Cyprus in Conflict and Community Media Participation. New York: Peter Lang.

3. Daly, G. 1996. Homeless: Policies, Strategies and Lives on the Street. London \& New York: Routledge.

4. Felski, R. 1999/2000. “The Invention of Everyday Life”, New Formations 39: 15-31.

5. Hammar, T. 1989. "State, Nation, and Dual Citizenship", in Immigration and the Politics of Citizenship in Europe and North America, ed. R. W. Brubaker. Lanham \& London: German Marshall Fund of the US, $81-95$.

6. Haraway, D. 1991. Simians, Cyborgs, and Women: The Reinvention of Nature. London: Free Association Press.

7. Harter, L. M.; Edwards, A.; McClanahan, A.; Hopson, M. C.; Carson Stern, E. 2004. “Organizing for Survival and Social Change: The Case of Street Wise", Communication Studies 55(2): 407-424.

8. Heidegger, M. 1993. Basic Writings (rev. edn; ed. D. F. Krell). London and New York: Routledge.

9. Hollows, J. 2008. Domestic Cultures. Maidenhead: Open University Press. 
10. Howley, K. 2003. "A Poverty of Voices: Street Papers as Communicative Democracy", Journalism 4(3): 273-292.

11. Howley, K. 2005. Community Media: People, Places, and Communication Technologies. Cambridge: Cambridge University Press.

12. Hughes-Edwards, M. 2006. “The House <...> Has Cancer': Representations of Domestic Space in the Poetry of Carol Ann Duffy", in Our House: The Representation of Domestic Space in Modern Culture, eds. G. Smyth and J. Croft. Amsterdam \& New York: Rodopi, 121-139.

13. Laclau, E.; Mouffe, C. 1985. Hegemony and Socialist Strategy: Towards a Radical Democratic Politics. London: Verso,

14. Levinson, D. 2004. Encyclopedia of Homelessness. 2 volumes. Thousand Oaks: Sage.

15. Maleuvre, D. 1999. Museum Memories: History, Technology, Art. Stanford, CA: Stanford University Press.

16. Marshall, T. H. 1992. "Citizenship and Social Class", in Citizenship and Social Class, eds. T. H. Marshall and T. B. Bottomore. London: Pluto Press, 1-51.

17. McCarthy, L. 2013. "Homelessness and Identity: A Critical Review of the Literature and Theory", People, Place \& Policy Online 7(1): 46-58. DOI: 10.3351/ppp.0007.0001.0004.

18. McNamara, R. 2008. Homelessness in America. 3 volumes. Santa Barbara: ABC-CLIO.

19. McVeigh, R. 1997. "Theorising Sedentarism: The Roots of Anti-nomadism", in Gypsy Politics and Traveller Identity, ed. T. Acton. Hertfordshire: University of Hertfordshire Press, 7-25.

20. Morley, D. 2000. Home Territories: Media, Mobility and Identity. New York, NY: Routledge.

21. Parsell, C. 2010. "Homeless Identities: Enacted and Ascribed", The British Journal of Sociology 62(3): 442-461.

22. Powell, R. 2008. "Understanding the Stigmatization of Gypsies: Power and the Dialectics of (Dis) identification", Housing, Theory and Society 25(2): 87-109.

23. Richter, A. G. 2005. Home on the Rails: Women, the Railroad, and the Rise of Public Domesticity. Chapel Hill \& London: University of North Carolina Press.

24. Schneider, B. 2011. "Sourcing Homelessness: How Journalists Use Sources to Frame Homelessness", Journalism 13(1): 71-86.

25. Smyth, G.; Croft, J. 2006. "Introduction: Culture and Domestic Space", in Our House: The Representation of Domestic Space in Modern Culture, eds. G. Smyth and J. Croft. Amsterdam \& New York: Rodopi, 11-26. 26. Snow, D.; Anderson, L. 1987. "Identity Work Among the Homeless: The Verbal Construction and Avowal of Personal Identities", American Journal of Sociology 92: 1336-1371.

27. Swain, J. 2011. "Busting the Myth", Inside Housing. Available at: https://www.insidehousing.co.uk/ comment/comment/busting-the-myth-29621

28. Torck, D. 2001. "Voices of Homeless People in Street Newspapers: A Cross-Cultural Exploration", Discourse \& Society 12(3): 371-392.

29. Tuchman, G. 1978. "Introduction: The Symbolic Annihilation of Women by the Mass Media", in Hearth and Home: Images of Women in the Mass Media, eds. G. Tuchman, A. K. Daniels and J. Benet. New York: Oxford University Press, 3-38.

30. Turner, B. S. 2016. "We Are All Denizens Now: On the Erosion of Citizenship", Citizenship Studies 20(6-7): 679-692.

31. Van Brussel, L. 2018. "The Right to Die: A Belgian Case Study Combining Reception Studies and Discourse Theory", Media, Culture \& Society 40(3): 381-396.

32. Wardhaugh, J. 1999. "The Unaccommodated Woman: Home, Homelessness and Identity", Sociological Review 47(1): 91-108.

33. Whang, I.; Min, E. 1999a. "Discourse Analysis of Television News on Public Antagonism against the Homeless", In Reading the Homeless: The Media's Image of Homeless Culture, ed. E. Min. Westport: Greenwood Publishing Group, 95-107.

34. Whang, I.; Min, E. 1999b. "Blaming the Homeless: The Populist Aspect of Network TV News", in Reading the Homeless: The Media's Image of Homeless Culture, ed. E. Min. Westport: Greenwood Publishing Group, 121-133. 
NICO CARPENTIER, VAIA DOUDAKI

\title{
Benamystès kaip diskursyvios politinès kovos konstravimas: diskursyvus teorinis benamio subjekto pozicijos perskaitymas
}

\begin{abstract}
Santrauka
Literatūroje apie benamystę didèja dẻmesys „benamio tapatumui“, nes šio tapatumo kompleksiška, atsitiktinè ir ginčijama prigimtis tampa vis labiau matoma. Straipsnyje siekiama diskutuoti šio diskurso tematika kartu su E. Laclau ir C. Mouffe tam, kad būtų teoriškai (diskursyviai) nusakytas benamystès tapatumas, diskursyviai teoriškai - benamio subjekto pozicija. Pripažistama, kad benamio subjekto pozicija yra didesnio darinio dalis ir siekiama parodyti ginčijamą šios subjekto pozicijos prigimtị ir tai, kaip tai tampa politinès kovos objektu. Antroje straipsnio dalyje analizuojama literatūra apie medijų konstravimą ir apie kovą dèl benamio subjekto pozicijos, taip pat vyraujanti kryptis medijose ir vadinamojoje gatvés spaudoje.
\end{abstract}

Raktažodžiai: poststruktūralistinè diskurso teorija, subjekto pozicija, benamystė, vyraujanti kryptis medijose, gatvès spauda 